\title{
Subglacial thermal balance permits ongoing grounding-line retreat along the Siple Coast of West Antarctica
}

\author{
Byron R. PARizeK, ${ }^{1}$ Righard B. Alley, ${ }^{1}$ Christina L. HUlBE ${ }^{2}$ \\ ${ }^{1}$ Department of Geosciences and EMS Environment Institute, The Pennsylvania State University, University Park, PA 16802-7501, U.S.A. \\ E-mail:parizek@essc.psu.edu \\ ${ }^{2}$ Department of Geology, Portland State University, Portland, OR 97207, U.S.A.
}

\begin{abstract}
Changes in the discharge of West Antarctic ice streams are of potential concern with respect to global sea level. The six relatively thin, fast-flowing Ross ice streams are of interest as low-slope end-members among Antarctic ice streams. Extensive research has demonstrated that these "rivers of ice" have a history of relatively high-frequency $(\leq \mathcal{O}(100)$ years), asynchronous discharge variations with evolving lateral boundaries. Amidst this variability, a $\sim 1300 \mathrm{~km}$ grounding-line retreat has occurred since the Last Glacial Maximum. Numerical studies of Ice Stream D (Parizek and others, 2002) indicate that a proposed thermal-regulation mechanism(Clarke and Marshall, 1998; Hulbe and MacAyeal, 1999; Tulaczyk and others, 2000a,b), which could buffer the West Antarctic ice sheet against complete collapse, may be over-ridden by latent-heat transport within meltwater from beneath inland ice. Extending these studies to Ice Stream A, Whillans Ice Stream and Ice Stream G suggests that further grounding-line retreat contributing to sealevel rise is possible thermodynamically. However, the efficiency of basal water distribution may be a constraint on the system. Because local thermal deficits promote basal freeze-on (especially on topographic highs), observed short-term variability is likely to persist.
\end{abstract}

\section{INTRODUGTION}

Predicting the future evolution of the West Antarctic ice sheet (WAIS) is an area of active research with global implications. While local changes in flow behavior have regional effects on ice-sheet mass balance, the potential for global impacts arises through cryospheric influence on global sea level and oceancirculation patterns. A majority of the ice in West Antarctica is tied up in the thick interior of the ice sheet, the discharge of which is dominated by internal deformation or slow basal motion leading to flow rates of meters to tens of meters per year. This interior basin feeds three main outlet systems, which deposit ice into the Weddell Sea, Pine Island Bay and Ross Sea, respectively. Much attention has been focused on the Ross Sea sector where the fast-moving Ross ice streams transport much of the grounded (non-floating) interior ice across the Siple Coast grounding line. Presently, ice flows at hundreds of meters per year in these streaming regions due to rapid basal sliding over, or deformation within, a well-lubricated subglacial till layer (Blankenship and others, 1986; Alley, 1989; Engelhardt and Kamb, 1998; Tulaczyk and others, 2000a; Kamb, 2001). Variations in this ice-drainage system have occurred at least since the Last Glacial Maximum (LGM) (Alley and Bindschadler, 2001). Despite a grounding-line advance to nearly the continental-shelf edge during the last glaciation and a subsequent $\sim 1300 \mathrm{~km}$ retreat, the ice streams maintained their characteristically low-elevation, low-slope surface profiles and existed in roughly their present locations (Conway and others, 1999; Anderson and Shipp, 2001).

The acceleration of ice from the inland region into the ice streams leads to a local thinning of the ice sheet. Ice-stream models that calculate a basal thermal budget for current con- ditions locally predict an associated increase in the basal thermal gradient that would dewater and strengthen the subglacial sediments to satisfy the local freezing tendency (Hulbe and MacAyeal, 1999; Tulaczyk and others, 2000b). Removal of the basal lubricant in Tulaczyk and others' (2000b) model slows the rapid ice motion and introduces unsteadiness that mimics the observed variability in the ice-stream system. Local thermal budgets have been used to argue that the ice streams are on the edge of the freeze/thaw boundary and that the post-glacial-maximum grounding-line retreat is on the brink of reversing itself (Clarke and Marshall, 1998; personal communication from S. Vogel and S. Tulaczyk, 2001). With more regional basal freezing, slowing and thickening of the ice streams would likely follow, accompanied by a grounding-line readvance.

However, field observations indicate substantial melting beneath the thicker inland ice (Engelhardt and Kamb, 1997, 1998; Kamb, 2001). That meltwater may supply lubrication and move latent heat downstream, thus satisfying local basal-thermal deficits. Based on the presence of a $>10 \mathrm{~m}$ debris-rich ice layer at the base of Ice Stream G (personal communication from $\mathrm{H}$. Engelhardt, 2001), it is apparent that a sub-ice-stream system of widespread, thin, interconnected, ice-contact braided channels (Walder and Fowler, 1994; Catania and Paola, 2001) was transporting regional water to balance the negative local budget for an extended period prior to the slow-down of the ice stream $\sim 150$ years ago (Retzlaff and Bentley, 1993; personal communication from S. Vogel and S. Tulaczyk, 2001; possible explanations for the slow-down are discussed by Anandakrishnan and others (2001) and Whillans and others (2001)). Not only is the frozenon layer too thick to have formed since Ice Stream C slowed, 
but the underlying sediments are still soft and are hence not yet dewatered (Kamb, 2001). A linked regional water system is therefore required. Similar debris-rich layers are found at the bases of Ice Stream D and Whillans Ice Stream (personal communication from H. Engelhardt, 2001).

While this basal water system has the potential to maintain the long-term persistence $(\mathcal{O}(10) \mathrm{kyr})$ of the ice streams (Conway and others, 1999; Anderson and Shipp, 2001; Parizek and others, 2002), the rapid variability $(\leq \mathcal{O}(100)$ years $)$ within this same hydrologic system (e.g. Alley and others, 1994; Engelhardt and Kamb, 1997) may allow for the marked unsteadiness observed in the glaciologic data (e.g. Retzlaff and Bentley, 1993; Bindschadler and Vornberger, 1998; Fahnestock and others, 2000). Parizek and others (2002) used numerical flowline sensitivity simulations along Ice Stream D to estimate its past and present "health" based on the total basal thermal budget of the combined inlandcatchment and ice-stream regions. The experimental results suggested that there is enough latent heat available in the modern basal water system to keep the ice stream away from the critical edge of freezing to its bed, thereby allowing for additional thinning and grounding-line retreat. Furthermore, a majority of the experiments predicted that the icestream bed was close to freezing at the LGM configuration and that postglacial climate changes increased basal lubrication greatly beginning sometime between 10 and $13 \mathrm{kyr}$, in close agreement with the onset of deglaciation (Conway and others, 1999). We extend this modeling effort to flowlines along Ice Stream A, Whillans Ice Stream and Ice Stream C.

\section{MODEL DESGRIPTION}

As presented in Parizek and others (2002), the Pennsylvania State University/University of Chicago flowline model (Cutler and others, 2000; Parizek, 2000) is computationally fast enough to allow multiple simulations varying key parameters through the appropriate parameter space over glacial-interglacial cycles on existing computers. The two-dimensional (vertical and along-flow) finite-element model incorporates Hermitian-polynomial interpolation functions across $20 \mathrm{~km}$ elements (based on MacAyeal, 1997). Ice dynamics is modeled with a diffusion formulation of the thin-ice approximation (Hutter, 1983) in which only the vertical shear stress drives ice deformation. At the scale used here, intra-element longitudinal stresses are negligible in the force balance (Whillans and Van der Veen, 1993). The flowlines are chosen to run along ice-stream center lines, thereby minimizing transverse stresses. Strain rate is set proportional to the third power of stress (Budd and Jacka, 1989). Sliding is parameterized as linear in basal shear stress with an adjustable prefactor set higher for the thin, low-surface-slope ice streams (e.g. region between onset and grounding line (g.l.) in Fig. 2a) and lower for the thicker inland ice (e.g. region between divide and onset in Fig. 2a) in order to simulate the effects of changing geology and to reconstruct reasonable LGM and modern profiles. Thermal subroutines account for both ice and bedrock. Within the ice, horizontal and vertical advection, vertical diffusion and viscous dissipation are included. Because we are interested in $\leq \mathcal{O}(100)$ kyr time-scales, heat flow in the bedrock is simulated using vertical diffusion with a prescribed thermalgradient boundary condition(generated by the regional geothermal flux) $1120 \mathrm{~m}$ below the ice (see Fig. 2a). The rock layer provides thermal inertia for temperature variations that reach the ice-bedrock interface. Following Le Meur and Huybrechts (1996), isostatic depression is calculated with an elastic lithosphere and relaxed asthenosphere.

The local basal heat budget is calculated as the sum of the geothermal and frictional heat flow "into" the ice-bedrock interface minus the heat conduction "out" from the interface and into the ice. Excess heat goes to melting while a deficit goes to freezing. Based on salt-tracer measurements in boreholes on Whillans Ice Stream (Engelhardt and Kamb, 1997), it is assumed that a throughgoing hydrologic system links the thermal states of inland and ice-stream beds on time-scales much shorter than the time-step sizes for either the dynamic or the longer thermodynamic routines. (Given observed flow rates of $7.5 \mathrm{~mm} \mathrm{~s}^{-1}$ and a $20 \mathrm{~km}$ horizontal nodal spacing, a parcel of water could travel across an element in approximately one simulated month.) Therefore, latent heat entering the hydrologic system due to up-glacier melting is instantly available to locations with a negative thermal budget such that the sum of heat along the flowline is a measure of ice-stream "health". While the complex and largely unobserved basal water system has been reduced to this one-dimensional idealization, thermal effects due to the lateral transfer of water into the ice stream are likely minimal as present borehole observations show that the interstream ridges are frozen to their beds (Engelhardt and Kamb, 1997; personal communication from H. Engelhardt, 2001).

Surface air temperatures are initialized with modern values along each flowline. Throughout the duration of each simulation, these temperatures are adjusted for elevation change (using an annual-average a diabatic lapse rate for West Antarctica of $5.1^{\circ} \mathrm{C} \mathrm{km}^{-1}$ (Fortuin and Oerlemans, 1990)) and climate change (using the 10-90 kyr Byrd Station's iceisotopic record, dated by Blunier and Brook (2001), converted to temperature change at $0.6 \%{ }^{\circ} \mathrm{C}^{-1}$, extended across the glacial cycle using Byrd Station's modern $-28^{\circ} \mathrm{C}$ at $0-10 \mathrm{kyr}$ and a linear trend to this value at $90-130 \mathrm{kyr}$ as displayed in Figure 3a). Sea-level changes affecting elevation, groundingline flotation thickness and lithospheric loading are taken from SPECMAP (Imbrie and others, 1984). The accumulation-rate parameterization assumes a $55 \%$ decrease for a $10^{\circ} \mathrm{C}$ cooling, initialized from local modern values (Huybrechts, 1992). These follow the approach that was used to model Ice Stream D in Parizek and others (2002).

\section{ICE-STREAM SIMULATIONS}

Eleven simulations for each ice stream considered here (Ice Stream A, Whillans Ice Stream and Ice Stream G) follow the respective flow paths displayed in Figure 1. Each simulation begins with a thermal spin-up from 300 to $130 \mathrm{kyr}$ under modern conditions and initially linear temperature gradients between specified surface temperature and initially thawed bed (Fig. 2a). Because the model does not treat ice-shelf dynamics, the flotation thickness is assigned at the modern grounding line throughout the spin-up period.

From 130 to $27.8 \mathrm{kyr}$, floating ice is artificially grounded on a very slippery bed that offers almost no resistance to flow in the "shelf" zone between the modern grounding line and ice front (Fig. 2a). The ice-stream domain for basal-thermal-budget calculations spans the zone between the onset region and the location where the ice has reached the local flotation thickness.

From $\sim 27.8$ to $12.9 \mathrm{kyr}$, the grounding line is fixed at the continental shelf edge (Conway and others, 1999). From 


\section{Flowline Domains}

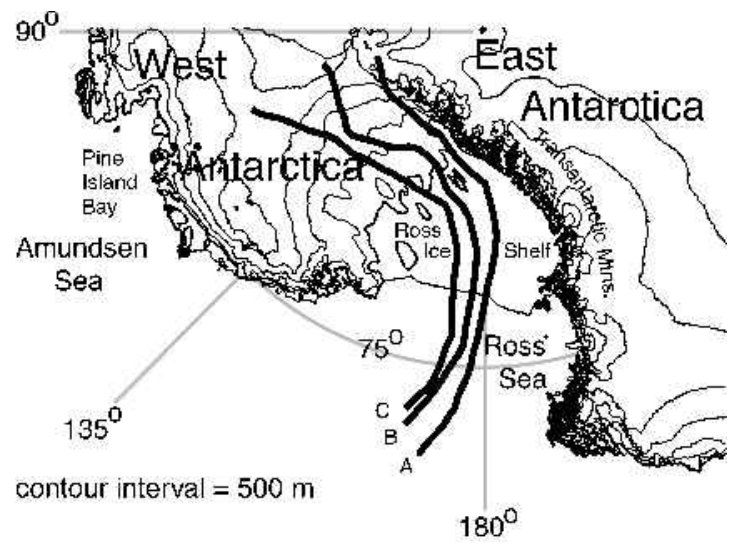

Fig. 1. Flowline-model domains, from divides down Ice Stream A, Whillans Ice Stream (B) and Ice Stream C and across the Ross embayment to the continental-shelf edge, from BEDMAP dataset (sponsored by the Scientific Committee on Antarctic Research and coordinated by the British Antarctic Survey, Cambridge, U.K.). $\sim 12.9$ kyr to the present, the grounding line is marched back from the LGM extent (e.g. Fig. 2b) to the modern position (e.g. Fig. 2c) at varying rates matching the "swinging gate" constrained by distributed geologic evidence (Conway and others, 1999). Throughout the last $27.8 \mathrm{kyr}$, all regions beyond the assigned grounding line are fixed as ice-free, thereby eliminating the need to include ice-shelf dynamics or specify a calving law in these data-driven simulations. In this way, errors associated with ignoring longitudinal stresses near the grounding line are minimized. We then determine what model conditions immediately preceded the known grounding-line retreat to help infer whether modern conditions are consistent with those that accompanied retreat.

Sensitivity experiments conducted on each flowline tested reasonable ranges of the geothermal flux, basal sliding conditions and accumulation rate on domains divided into three distinct basal regions (see Fig. 2a): "sheet" (divide to fixed modern onset region for sliding and thermal-budget calculations), "stream" (modern onset to modern grounding line for sliding calculations and variable region from modern onset to assigned grounding-line position for thermalbudget calculations) and "shelf" (variable region between the modern grounding line and ice front (assigned grounding line) during the period spanning $\sim 130-27.8 \mathrm{kyr}$

Table 1. Thermal-budget simulations for flowlines $A, B$ and $C$

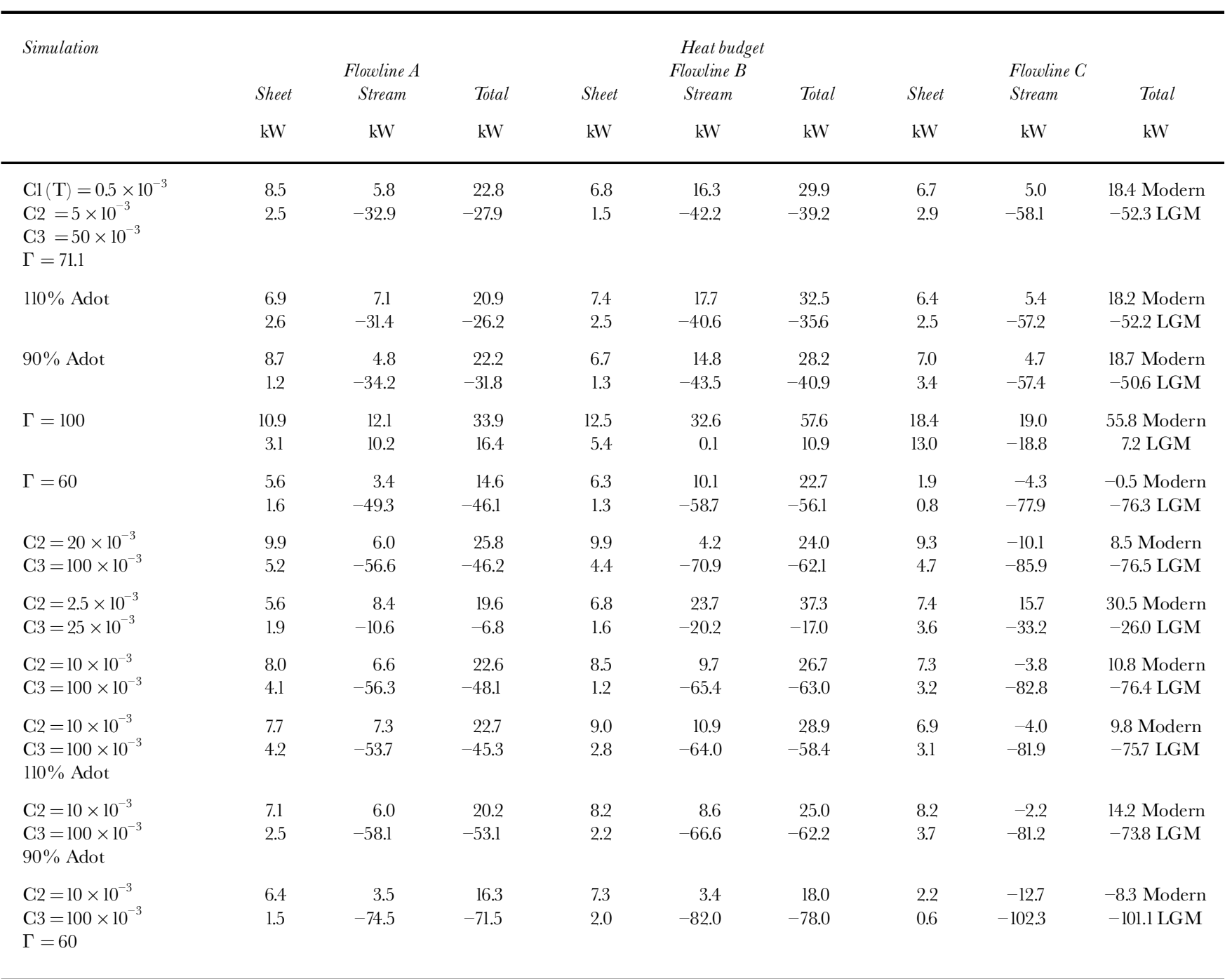

Notes: Details of 11 simulations for each flowline. C1, C2 and C3 are sheet, stream and shelf sliding factors $\left(\mathrm{m} \mathrm{a}^{-1} \mathrm{~Pa}^{-1}\right)$, applied either always $(\mathrm{C})$ or only when thawed locally $(\mathrm{C}(\mathrm{T})) . \Gamma$ is geothermal flux $\left(\mathrm{mW} \mathrm{m}^{-2}\right)$ and Adot is accumulation rate. Budgets are calculated over the modern sheet and evolving stream domains. "Total" balances assume $2: 1$ width ratio for sheet/stream. 

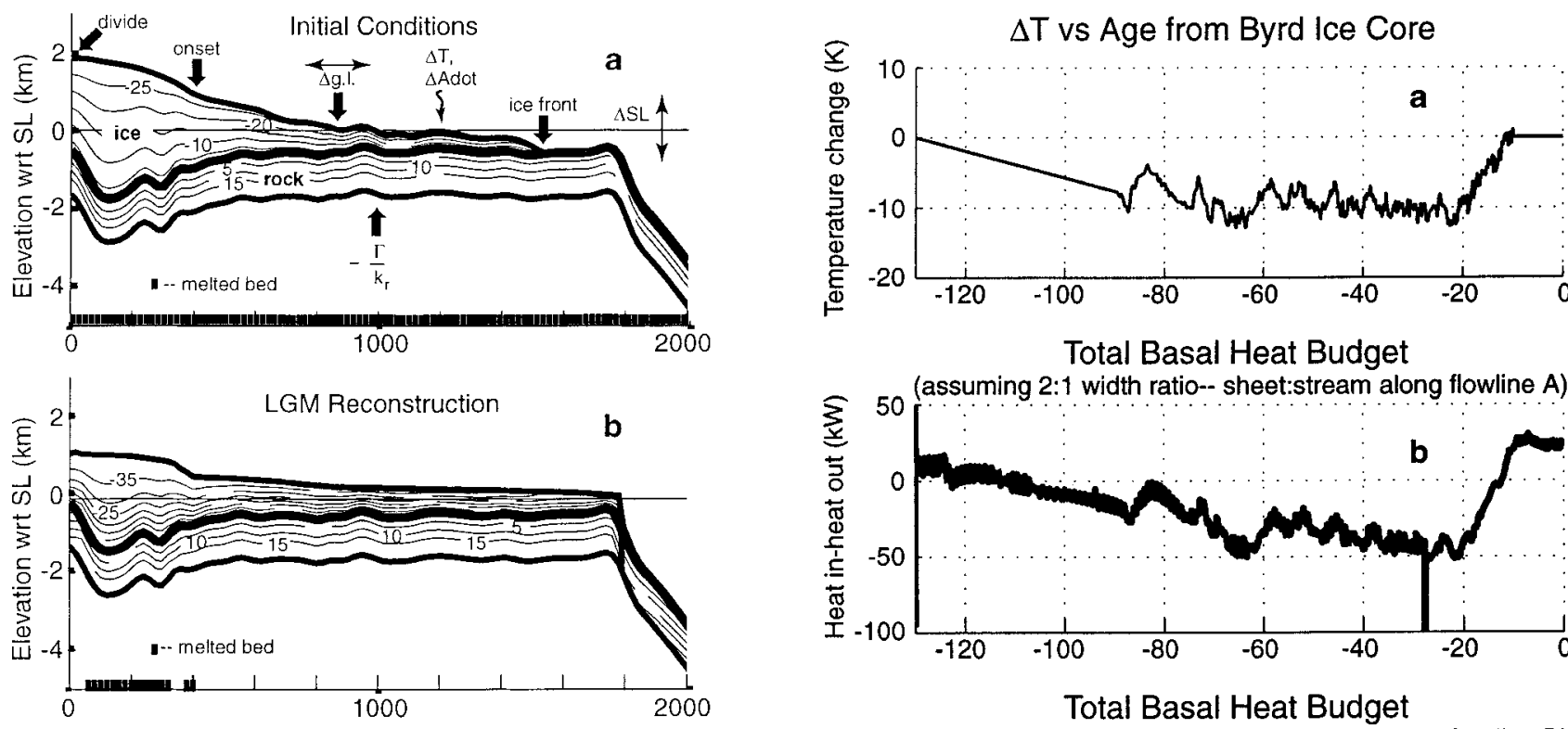

Total Basal Heat Budget

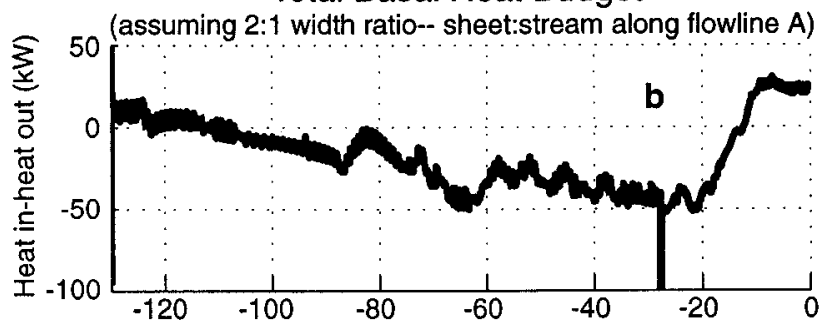

Total Basal Heat Budget
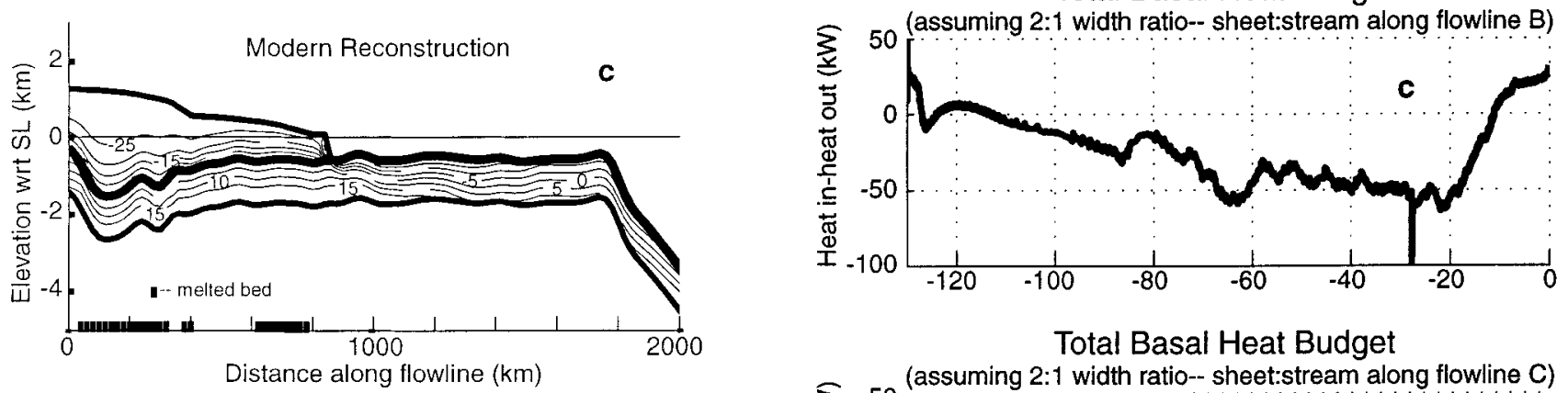

Total Basal Heat Budget

Fig. 2. (a) Initial conditions including isotherms along the flowline through Ice Stream C; (b) LGM (22.1 kyr); and (c) modern ice-sheet reconstructions with basal melting, from eighth simulation on Ice Stream C ( Table 1).

(27.8 kyr-present) for sliding). All runs permit sliding in the "stream" and "shelf" zones regardless of the local thermal conditions at the bed. Along with the "shelf" sliding enhancement between the modern and assigned grounding lines (130 kyr-present), this promotes thin, flat ice-stream profiles (Conway and others, 1999; Anderson and Shipp, 2001), thereby encouraging modeled basal freeze-on by increasing the thermal gradient within the ice. In addition, all artificial melt generated at the slope breaks between sliding regimes is completely removed from the thermal budget. The steep surface slopes that are generated at these locations lead to anomalously high local driving stresses that produce added meltwater. By removing this excess heat, we eliminate the melting bias from the simulations, driving the ice streams even closer to the freeze-on threshold. While strain heating within the ice column also increases at these nick points, the net effect across these transition zones in nature and model is comparable. Because the transition occurs more gradually in nature than in the model, excess simulated strain heating at the artificial nick point is compensated by a modeled shortfall immediately down-glacier. (Inclusion of longitudinal stresses in the force-balance calculations would smooth out the nick points and lead to more uniform meltwater production across the transition regions (Price and others, 2002).) Sliding in the "sheet" domain occurs only where the local basal temperature reaches the pressure-melting point. For calculations of available basal water only, the sheet region is assumed to be twice

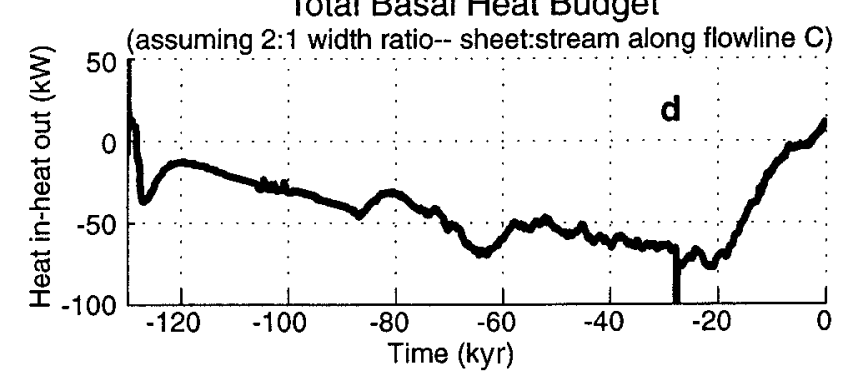

Fig. 3. (a) $130 \mathrm{kyr}$ temperature forcing. (b-d) History of basal heat budget, for eighth simulation (Table 1): flowline $A(b)$; flowline $B(c)$; and flowline $C(d)$. Total heat budgets are calculated assuming catchment sheet is twice as wide as stream. In each simulation, the sharp negative imbalance at $27.8 \mathrm{kyr}$ is a result of the initial assignment of the flotation thickness at the LGM grounding line and should not be interpreted as a physical phenomenon.

as wide as the stream based on modern observations (Joughin and others, 1999).

\section{RESULTS}

Meltwater is produced throughout the climate cycle, though its effect on the energy budget of each ice stream varies during the cycle. In 31 of the 33 simulations conducted here, enough meltwater is produced along each flowline to prohibit freezeon of the modern ice streams (see Table 1). The tendency to shut-down is observed only on Ice Stream $\mathrm{C}$ when the regional geothermal flux is reduced to $60 \mathrm{~mW} \mathrm{~m}^{-2}$. During the LGM, basal melting is restricted to bedrock overdeepenings beneath the ice-stream catchments (e.g. Fig. 2b). The quantity of LGM meltwater production is insufficient to balance the freezing tendencies of the ice streams for all but one para- 
meter configuration. The lower accumulation rates during the last glaciation act to warm the bed in these simulations, but the colder temperatures and reduced frictional heating from decreased flow speeds simply cool the bed more. While data support streaming flow throughout the LGM, it persists in the simulations only when we increase the regional geothermal flux to $100 \mathrm{~mW} \mathrm{~m}^{-2}$. The simulated shut-down of all ice streams may be due to the omission of flow convergence from sheet to stream, which results in somewhat thinner inland ice (cf. modern profiles in Fig. 2a and c) and an underestimation of upstream basal melting. Somewhat thicker LGM inland ice may have fed slightly thicker and slower ice streams, which in turn would have contributed to the LGM grounding-line advance. Similar to the findings for Ice Stream D (Parizek and others, 2002), several experiments predict that sufficient lubrication for thawed basal conditions out to the grounding line is restored sometime between 10 and 13 kyr (e.g. Fig. 3b and c).

\section{DISGUSSION AND GONGLUSIONS}

With the recent slowing and thickening of Whillans Ice Stream and the local freezing tendencies inferred from measured borehole temperature profiles and observed basal debris layers within several ice streams, it has been theorized that the modern ice streams are cooling at depth and consuming their lubricant via basal freezing. However, conservative numerical simulations along Ice Stream A, Whillans Ice Stream and Ice Stream C suggest that meltwater production inland and within bedrock lows can overcome the local freezing tendency along the modern ice streams. Previous work concluded the same for Ice Stream D (Parizek and others, 2002). Using a semi-empirical technique, Joughin and others (2003) reached a similar conclusion, increasing confidence in the results.

The LGM ice streams were likely slower than their modern counterparts as indicated by lower LGM accumulation rates combined with data suggesting ice-stream geometries similar to today's (Conway and others, 1999; Anderson and Shipp, 2001). The modeled LGM reduction in production of lubricating basal meltwater is consistent with these observations. Furthermore, many of the simulations indicate that regional basal melting initially exceeded freezing sometime between 10 and $13 \mathrm{kyr}$, in accord with the onset of deglaciation (Conway and others, 1999). It is not hard to imagine a resulting feedback mechanism for retreat: additional lubrication leading to faster ice flow, thinning in the Ross embayment, and ultimately flotation and retreat of the grounding line.

Both model and data suggest further thinning and grounding-line retreat are thermally viable, via a throughgoing basal meltwater system (e.g. personal communication from $\mathrm{H}$. Engelhardt, 2001; Kamb, 2001; cf. Joughin and Tulaczyk, 2002). Local variability within the hydrologic system promotes either lubrication or freeze-on, depending on the local meltwater flow pattern. Therefore, observed short-term variability within the ice-stream system is likely to persist amidst continued ice streaming along the Siple Coast.

\section{AGKNOWLEDGEMENTS}

This work was supported by a NASA Goddard Space Flight Center (GSFG) Graduate Student Researchers Program Fellowship (to B. R. Parizek). This material is based in part upon work supported by the U.S. National Science Foundation under grants including Nos. 0126187 and 9814774. We are grateful to S. Anandakrishnan, R. A. Bindschadler, H. B. Conway, D. R. MacAyeal and M. Fahnestock for their contributions. Critical reviews by M.J. Sharp and an anonymous referee helped improve the clarity of the manuscript. Additional thanks to the Scientific Editor, H. Engelhardt, for his constructive remarks. Special thanks to H.H. Parizek for her encouragement throughout this research effort.

\section{REFERENGES}

Alley, R. B. 1989. Water-pressure coupling of sliding and bed deformation: I. Water system. F. Glaciol., 35(119), 108-118.

Alley, R. B. and R. A. Bindschadler, eds.. 2001. The West Antartic ice sheet: behavior and environment. Washing ton, DC, American Geophysical Union. (Antarctic Research Series 77.)

Alley, R. B., S. Anandakrishnan, C. R. Bentley and N. Lord. 1994. A waterpiracy hypothesis for the stagnation of Ice Stream C, Antarctica. Ann Glaciol., 20, 187-194.

Anandakrishnan, S., R. B. Alley, R.W. Jacobel and H. Conway. 2001. The flow regime of Ice Stream $\mathrm{C}$ and hypotheses concerning its recent stagnation. In Alley, R. B. and R. A. Bindschadler, eds. The West Antarctic ice sheet: behavior and environment. Washington, DC, American Geophysical Union, 283-294. (Antarctic Research Series 77.)

Anderson, J. B. and S. S. Shipp. 2001. Evolution of the West Antarctic ice sheet. In Alley, R. B. and R. A. Bindschadler, eds. The West Antarctic ice sheet: behavior and environment. Washington, DC, American Geophysical Union, 45-57. (Antarctic Research Series 77.)

Bindschadler, R. and P. Vornberger. 1998. Changes in the West Antarctic ice sheet since 1963 from declassified satellite photography. Science, 279(5351), 689-692.

Blankenship, D. D., C. R. Bentley, S.T. Rooney and R. B. Alley. 1986. Seismic measurements reveal a saturated porous layer beneath an active Antarctic ice stream. Nature, 322(6074), 54-57.

Blunier, T. and E. J. Brook. 2001. Timing of millennial-scale climate change in Antarctica and Greenland during the last glacial period. Science, $291(5501), 109-112$.

Budd, W. F. and T. H. Jacka. 1989. A review of ice rheology for ice sheet modelling. Cold Reg. Sci. Technol., 16(2), 107-144.

Catania, G. and C. Paola. 2001. Braiding under glass. Geology, 29(3), 259-262.

Clarke, G. K. C. and S. J. Marshall. 1998. Critical state hypothesis for subpolar glaciers and ice sheets. [Abstract.] Eos, 79(45), Fall Meeting Supplement, F310.

Conway, H., B. L. Hall, G. H. Denton, A. M. Gades and E. D. Waddington. 1999. Past and future grounding-line retreat of the West Antarctic ice sheet. Science, 286(5438), 280-283.

Cutler, P. M., D. R. MacAyeal, D. M. Mickelson, B. B. Parizek and P. M Colgan. 2000. A numerical investigation of ice-lobe-permafrost interaction around the southern Laurentide ice sheet. F. Glaciol., 46(153), 311-325.

Engelhardt, H. and B. Kamb. 1997. Basal hydraulic system of a West Antarctic ice stream: constraints from borehole observations. F. Glaciol., 43(144), 207-230.

Engelhardt, H. and B. Kamb. 1998. Basal sliding of Ice Stream B, West Antarctica. 7. Glaciol., 44(147), 223-230.

Fahnestock, M. A., T. A. Scambos, R. A. Bindschadler and G. Kvaran. 2000 A millennium of variable ice flow recorded by the Ross Ice Shelf, Antarctica. 7. Glaciol., 46(155), 652-664.

Fortuin, J. P. F. and J. Oerlemans. 1990. Parameterization of the annual surface temperature and mass balance of Antarctica. Ann. Glaciol., 14, 78-84.

Hulbe, C. L. and D. R. MacAyeal. 1999. A new numerical model of coupled inland ice sheet, ice stream, and ice shelf flow and its application to the West Antarctic ice sheet. 7. Geophys. Res., 104(B11), 25,349-25,366.

Hutter, K. 1983. Theoretical glaciology; material science of ice and the mechanics of glaciers and ice sheets. Dordrecht, etc., D. Reidel Publishing Co.; Tokyo, Terra Scientific Publishing Co.

Huybrechts, P. 1992. The Antarctic ice sheet and environmental change: a three-dimensional modelling study. Ber. Polarforsch. 99.

Imbrie, J. and 8 others. 1984. The orbital theory of Pleistocene climate: support from a revised chronology of the marine $\delta^{18} \mathrm{O}$ record. In Berger, A., J. Imbrie, J. Hays, G. Kukla and B. Saltzman, eds. Milankovitch and climate: understanding the response to astronomical forcing. Part 1. Dordrecht, etc., D. Reidel Publishing Co., 269-305. (NATO ASI Series C: Mathematical and Physical Sciences 126.)

Joughin, I. and S. Tulaczyk. 2002. Positive mass balance of the Ross Ice 
Streams, West Antarctica. Science, 295(5554), 476-480.

Joughin, I. and 7 others. 1999. Tributaries of West Antarctic ice streams revealed by RADARSAT interferometry. Science, 286(5438), 283-286.

Joughin, I. R., S. Tulaczyk and H. Engelhardt. 2003. Basal melt beneath Whillans Ice Stream and Ice Streams A and C. Ann. Glaciol., 36 (see paper in this volume).

Kamb, B. 2001. Basal zone of the West Antarctic ice streams and its role in lubrication of their rapid motion. In Alley, R. B. and R. A. Bindschadler, eds. The West Antarctic ice sheet: behavior and environment. Washington, DC, American Geophysical Union, 157-199. (Antarctic Research Series 77.)

Le Meur, E. and P. Huybrechts. 1996. A comparison of different ways of dealing with isostasy: examples from modelling the Antarctic ice sheet during the last glacial cycle. Ann. Glaciol., 23, 309-317.

MacAyeal, D. R. 1997. Lessons in ice sheet modeling. Revised edition. Chicago, IL, University of Chicago. Department of Geophysical Sciences.

Parizek, B. R. 2000. Thermomechanical flowline model for studying the interactions between ice sheets and the global climate system. (M.Sc. thesis, The Pennsylvania State University.)

Parizek, B. R., R. B. Alley, S. Anandakrishnan and H. Conway. 2002. Subcatchment melt and long-term stability of Ice Stream D, West Antarctica. Geophys. Res. Lett., 29(8), 551-554.
Price, S. F., R. A. Bindschadler, C. L. Hulbe and D. D. Blankenship. 2002. Force balance along an inland tributary and onset to Ice Stream D, West Antarctica. 7. Glaciol., 48(160), 20-30.

Retzlaff, R. and C. R. Bentley. 1993. Timing of stagnation of Ice Stream C, West Antarctica, from short-pulse radar studies of buried surface crevasses. f. Glaciol., 39(133), 553-561.

Tulaczyk, S. M., B. Kamb and H. F. Engelhardt. 2000a. Basal mechanics of Ice Stream B, West Antarctica. I. Till mechanics. F. Geophys. Res., 105(B1), 463-481.

Tulaczyk, S. M., B. Kamb and H. F. Engelhardt. 2000b. Basal mechanics of Ice Stream B, West Antarctica. II. Undrained-plastic-bed model. f. Geophys. Res., $105(\mathrm{Bl}), 483-494$.

Walder, J. S. and A. Fowler. 1994. Channelized subglacial drainage over a deformable bed. F. Glaciol., 40(134), 3-15.

Whillans, I. M. and C. J. van derVeen. 1993. New and improved determinations of velocity of Ice Streams B and C, West Antarctica. 7. Glaciol., 39(133), 483-490.

Whillans, I. M., C. R. Bentley and C. J. van der Veen. 2001. Ice Streams B and C. In Alley, R. B. and R. A. Bindschadler, eds. The West Antarctic ice sheet: behavior and environment. Washington, DC, American Geophysical Union, 257-281. (Antarctic Research Series 77. 